\title{
PPP2CB Gene
}

National Cancer Institute

\section{Source}

National Cancer Institute. PPP2CB Gene. NCI Thesaurus. Code C20399.

This gene is involved in the negative control of cell growth and division. 